\title{
PERAN KINERJA PEGAWAI DALAM MEMEDIASI DAMPAK TATA KELOLA PERUSAHAAN TERHADAP KINERJA KEUANGAN
}

\author{
Ary Yunanto ${ }^{1 *}$, Refius Pradipta Setyanto ${ }^{1}$ \\ ${ }^{1} J u r u s a n$ Manajemen, Fakultas Ekonomi dan Bisnis, Universitas Jenderal Soedirman, Indonesia \\ *Email corresponding author: ary.yunanto@unsoed.ac.id \\ Diterima 27/11/2019 Direvisi 17/09/2020 Diterbitkan 30/09/2020
}

\begin{abstract}
Abstrak
Penelitian ini memiliki tujuan untuk mengetahui pengaruh penerapan prinsip-prinsip tata kelola perusahaan terhadap kinerja keuangan yang dimediasi oleh kinerja pegawai. Populasi dalam penelitian ini adalah seluruh pegawai yang bekerja pada kantor BPR BKK Purwokerto Kabupaten Banyumas. Pemilihan sampel didasarkan pada metode pengambilan sampel bertujuan (purposive sampling). Data yang digunakan dalam penelitian ini dianalisis menggunakan partial least square dan dilakukan dengan bantuan perangkat lunak smart PLS. Hasil penelitian menunjukkan bahwa tata kelola perusahaan memiliki efek positif pada kinerja keuangan. Selain itu, hasil penelitian juga menunjukkan kinerja pegawai memediasi pada dampak tata kelola perusahaan terhadap kinerja keuangan.

Kata Kunci: Tata Kelola Perusahaan, Kepuasan Pegawai dan Kinerja Keuangan.
\end{abstract}

\begin{abstract}
This study aims to determine the effect of applying the principles of corporate governance on financial performance mediated by employee performance. The population in this study are all employees who work at BPR BKK Purwokerto Banyumas Regency office. Sample selection is based on purposive sampling method. The data used in this study were analyzed using partial least square and performed with smart PLS software. The results showed that corporate governance has a positive effect on financial performance. In addition, the results of the study also indicate that employee performance mediates on the impact of corporate governance on financial performance.
\end{abstract}

Key Words: Corporate Governance, Employee Performance and Financial Performance.

\section{PENDAHULUAN}

Bank Perkreditan Rakyat (BPR) merupakan salah satu lembaga keuangan formal yang memiliki fungsi sebagai lembaga intermediasi keuangan khususnya pada sistem keuangan mikro nasional (Tim Pedoman Akutansi Bank Perkreditan Rakyat, Bank Indonesia, 2010). Keberadaan BPR sebagai salah satu jenis bank yang banyak melayani masyarakat ekonomi kecil dan menengah serta golongan pengusaha mikro kecil dan menengah telah terbukti sangat bermanfaat. Berdasarkan hal tersebut, penilaian kinerja keuangan BPR menjadi hal yang sangat penting. Selain dapat menunjukkan bank itu sehat atau tidak, hasil penilaian tersebut juga akan bermanfaat bagi manajemen bank maupun pihak lain di luar bank yang berkepentingan.

Namun demikian, berdasarkan siaran pers Otoritas Jasa Keuangan (OJK) terhitung dari tahun 2018 sampai dengan tahun 2020 atau selama tiga tahun terakhir OJK telah menutup sebanyak 17 BPR. Dengan rincian pada tahun 2018 sebanyak 6 BPR, tahun 2019 sebanyak 6 BPR dan tahun 2020 sebanyak 5 BPR, secara umum penutupan BPR tersebut diakibatkan kinerja keuangan yang bermasalah. Kejadian banyaknya penutupan BPR di Indonesia oleh OJK membuktikan bahwa industri perbankan di Indonesia sangat penuh dengan risiko sehingga membutuhkan regulasi dan 
Performance. Volume 27 Nomor 2 Tahun 2020, 39-48

pengawasan yang lebih ketat agar tidak menyebabkan penurunan kepercayaan masyarakat terhadap bank (Kangmartono et al., 2018).

Kinerja keuangan akan makin baik dan dapat terus unggul dalam persaingan, jika ada perbaikan yang dilaksanakan secara terus menerus. Untuk itu, diperlukan keberadaan peraturan dan mekanisme pengendalian yang secara efektif mengarahkan kegiatan operasional perusahaan serta kemampuan untuk mengidentifikasi pihak-pihak yang mempunyai kepentingan yang berbeda. Mekanisme untuk memperbaiki dan memaksimalkan kinerja keuangan tersebut adalah penerapan tata kelola yang baik dalam organisasinya atau lebih dikenal dengan good corporate governance (Laksana, 2015). Beberapa peneliti berpendapat bahwa penyelidikan khusus atau karakteristik khusus tata kelola perusahaan mungkin tidak mencerminkan pengaruh tata kelola, dan mereka telah mencoba untuk mengevaluasi hubungan keseluruhan antara tata kelola perusahaan dan kinerja perusahaan (Bauer et al. 2008).

Hasil studi literatur empiris menunjukkan masih terdapat perbedaan hasil penelitian pengaruh corporate governance terhadap kinerja keuangan BPR. Hasil penelitian pada BPR di Indonesia yang dilakukan oleh Adriyan dan Supatmi (2010) menemukan bahwa mekanisme tata kelola perusahaan secara simultan berpengaruh terhadap kinerja keuangan BPR di Jawa Tengah. Hasil penelitian ini menunjukkan bahwa perusahaan dengan nilai corporate governance yang tinggi memiliki marjin laba bersih dan laba per saham yang lebih tinggi. Sementara perusahaan yang memiliki nilai corporate governance yang lebih rendah memiliki marjin laba bersih dan laba per saham yang lebih rendah. Hal ini menunjukkan bahwa perusahaan dengan nilai corporate governance yang lebih tinggi, lebih menguntungkan dan memiliki kinerja yang lebih baik. Sedangkan hasil penelitian lain yang dilakukan Kangmartono et al., (2018) menunjukkan bahwa secara parsial, Capital Adequacy Ratio dan Jumlah Dewan Komisaris berpengaruh positif signifikan terhadap kinerja keuangan BPR, sedangkan Jumlah Board of Directors berpengaruh negatif signifikan terhadap kinerja keuangan BPR. Namun demikian, hasil penelitian Aboagye dan Otieku (2010) menemukan bahwa penerapan tata kelola perusahaan tidak berpengaruh terhadap kinerja keuangan pada perusahaan Bank Perkreditan Rakyat (rural bank) di Ghana.

Disisi lain, perspektif teori agensi merupakan dasar yang digunakan untuk memahami isu tata kelola perusahaan (corporate governanace). Teori keagenan menyangkut hubungan kontraktual antara anggota-anggota di perusahaan. Hubungan agensi terjadi ketika satu orang atau lebih (prinsipal) mempekerjakan orang lain (agen) untuk memberikan suatu jasa dan kemudian mendelegasikan wewenang pengambilan keputusan (Jensen and Meckling, 1976). Pemisahan kepemilikan pada institusi perbankan dapat menimbulkan benturan kepentingan (conflict of interest) jika tidak dilakukan pengawasan. Benturan kepentingan adalah perbedaan antara kepentingan ekonomis perusahaan dengan kepentingan ekonomi pribadi direktur dan komisaris serta jajaran di bawahnya, pemegang saham atau pihak terafiliasi dari direktur, komisaris atau pemegang saham, yang dapat merugikan bank.

Tata kelola perusahaan yang baik (good corporate governance) menjadi peraturan yang mengatur hubungan antara seluruh pihak (internal dan eksternal) dalam perusahaan, berkaitan dengan kewajiban dan hak-hak mereka. Hasil penelitian Amri et al (20016) dan Febriani et al. (2016) menemukan bahwa variabel good corporate governance berpengaruh positif terhadap kinerja pegawai. Sementara itu, peningkatan kinerja pegawai akan memberikan kontribusi yang positif terhadap perkembangan bisnis perusahaan sehingga semakin baik kinerja pegawai maka semakin baik kinerja keuangan perusahaan (Hatane, 2015)

Terkait dengan riset gap penelitian terdahulu serta melihat pada fenomena yang terjadi terhadap banyaknya BPR di Indonesia yang ditutup karena kinerja keuangan yang buruk maka penelitian ini bertujuan untuk menemukan bukti empiris pengaruh tidak langsung mekanisme tata kelola perusahaan (corporate governance) terhadap kinerja keuangan (financial 


\section{PERFORMANCE}

Jurnal Personalia, Financial, Operasional,

Marketing dau Sistem Informasi

Performance. Volume 27 Nomor 2 Tahun 2020, 39-48

performance) melalui kinerja pegawai (employee performance) pada salah satu Bank Perkreditan Rakyat.

\section{TINJAUAN PUSTAKA DAN PERUMUSAN HIPOTESIS}

Evolusi pemikiran tentang tata kelola perusahaan berawal dari konsekuensi ketika memisahkan antara kontrol dan kepemilikan perusahaan (Berle and Means, 1932) dan kemudian Jensen and Meckling (1976) mengenai teori agensi. Tata kelola perusahaan (corporate governance) didefinisikan oleh OECD (2004) sebagai suatu prosedur dan proses yang digunakan untuk mengarahkan dan mengendalikan perusahaan. Oleh karena itu struktur tata kelola perusahaan menentukan hak dan tanggung jawab yang berbeda antara peserta dalam organisasi seperti dewan direksi, manajer, pemegang saham dan stakeholders lainnya serta menetapkan aturan-aturan dan prosedur untuk pembuatan keputusan. Implementasi dari tata kelola perusahaan dilakukan oleh seluruh pihak dalam perusahaan, dengan aktor utamanya adalah manajemen puncak perusahaan yang berwenang untuk menetapkan kebijakan perusahaan dan mengimplementasikan kebijakan tersebut.

Penerapan tata kelola perusahaan yang baik akan memperbaiki citra bank (Atmaja et al., 2015). Manajemen sebagai pihak yang diberi mandat oleh pemilik modal untuk mengoperasikan perusahaan, perlu dipantau terus-menerus. Kepentingan berbeda yang dimiliki oleh pemilik modal dan manajemen dapat menyebabkan disintegrasi dalam perusahaan (Andriana and Panggabean, 2017). Dengan menerapkan tata kelola perusahaan yang baik maka wewenang semua pihak dalam perusahaan dapat diatur dan fungsi pengawasan dapat dioptimalkan untuk mengurangi terjadinya ketidakberesan yang dilakukan oleh berbagai pihak di perusahaan. Hal tersebut akan berpengaruh positif terhadap kinerja keuangan perusahaan.

Penerapan tata kelola perusahaan (corporate governance) pada perusahaan akan meningkatkan kinerja perusahaan tersebut. Xu and Xia (2012) menyatakan bahwa keberadaan tata kelola perusahaan diharapkan dapat mengurangi konflik kepentingan sehingga dapat meningkatkan kinerja keuangan perusahaan. Hasil penelitian dari Ahmed dan Hamdan (2015), dan Mahrani and Soewarno (2018), Yilmaz (2018), Paniagua et al., (2018), Saidat et al., (2018), Situmorang dan Simanjuntak (2019) menemukan bukti bahwa tata kelola perusahaan (corporate governance) berpengaruh positif terhadap kinerja keuangan. Berdasarkan penjelasan di atas maka dapat dirumuskan hipotesis sebagai berikut:

\section{H1: Tata kelola perusahaan berpengaruh secara positif terhadap kinerja keuangan.}

Pengelolaan perusahaan dapat dilakukan secara terbuka/transparan dengan keberadaan mekanisme corporate governance sehingga perilaku manajemen dapat dikendalikan. Mengingat semakin ketatnya persaingan antar perusahaan dewasa ini menuntut perusahaan harus mampu bertahan dan berkompetisi dengan perusahaan lain, salah satu hal yang dapat ditempuh perusahaan agar mampu bertahan dalam persaingan yang ketat adalah dengan menerapkan tata kelola perusahaan yang baik. Peranan sumber daya manusia dalam perusahaan sangatlah penting kerena sebagai penggerak utama seluruh kegiatan atau aktivitas perusahaan dalam mencapai tujuannya. Berhasil tidaknya suatu perusahaan dalam mempertahankan eksitensi perusahaan dimulai dari manusia itu sendiri dalam mempertahankan perusahaan dalam meningkatkan afektivitas dan efisiensi secara maksimal (Amri et al. 2016).

Kinerja pada dasarnya merupakan apa yang dilakukan atau tidak dilakukan pegawai sehingga kinerja pegawai merupakan fungsi dari interaksi antara kemampuan dan motivasi. Prinsip-prinsip good corporate governance pada dasarnya memiliki tujuan memberikan kemajuan terhadap kinerja suatu perusahaan termasuk di dalamnya pegawai. Hasil penelitian Amri et al (20016), Febriani et al. (2016) dan Hamdani et al., (2018) menemukan bahwa variabel good corporate 


\section{PERFORMANCE}

Jurnal Personalia, Financial, Operasional,

Marketing dau Sistem Informasi

Performance. Volume 27 Nomor 2 Tahun 2020, 39-48

governance berpengaruh positif terhadap kinerja pegawai. Berdasarkan penjelasan diatas maka dapat dirumuskan hipotesis sebagai berikut:

\section{H2: Tata kelola perusahaan berpengaruh secara positif terhadap kinerja pegawai.}

Kinerja pegawai merujuk pada kontribusi para pegawai terhadap perusahaan (Mathias dan Jakson, 2002). Kinerja pegawai merupakan faktor penting yang berkontribusi untuk meningkatkan hasil, meningkatkan perilaku positif dan karakteristik pegawai, serta membantu meningkatkan produktivitas organisasi (Zahargier and Balasundaram, 2011). Bratton (2004) mencatat bahwa teori peristiwa afektif memberikan kerangka kerja untuk memahami peristiwa yang menghasilkan respons emosional pada pegawai dengan menyarankan bahwa respons ini mengarah pada implikasi jangka panjang bagi suatu organisasi, termasuk sikap, perilaku, dan kinerja pegawai. Menyelidiki hubungan antara kinerja pegawai dan kinerja perusahaan menyiratkan pentingnya pegawai bagi organisasi. Hasil penelitian Hatane (2015) membuktikan bahwa kinerja pegawai berengaruh positif terhadap kinerja keuangan. Berdasarkan penjelasan diatas maka dapat dirumuskan hipotesis sebagai berikut:

\section{H3: Kinerja pegawai berpengaruh secara positif terhadap kinerja keuangan.}

Peranan sumber daya manusia dalam perusahaan sangatlah penting kerena sebagai penggerak utama seluruh kegiatan atau aktivitas perusahaan dalam mencapai tujuannya. Berhasil tidaknya suatu perusahaan dalam mempertahankan eksitensi perusahaan dimulai dari manusia itu sendiri dalam mempertahankan perusahaan dalam meningkatkan efektivitas dan efisiensi secara maksimal. Suatu perusahaan selain memiliki keunggulan kompetitif yang bertujuan untuk memenangkan persaingan didalam lingkungan bisnis, perusahaan juga menggunakan keunggulan kompetitif sebagai salah satu cara untuk mencapai tujuan kinerja yang diinginkan.

Kinerja perusahaan merupakan hasil sesungguhnya atau output yang dihasilkan dari sebuah perusahaan yang kemudian diukur dan dibandingkan dengan hasil atau output yang diharapkan. Hasil penelitian Ahmed dan Hamdan (2015) dan Mahrani and Soewarno (2018) menemukan bukti bahwa tata kelola perusahaan (corporate governance) berpengaruh positif terhadap kinerja keuangan. Selain itu, hasil penelitian lain yang dilakukan oleh Amri et al (20016) dan Febriani et al. (2016) menemukan bukti bahwa variabel good corporate governance juga berpengaruh positif terhadap kinerja pegawai. Sementara itu, hasil penelitian Hatane (205) membuktikan bahwa kinerja pegawai berpengaruh positif terhadap kinerja keuangan. Komitmen manajemen puncak untuk meningkatkan kepuasan pegawai dengan mempertimbangkan faktor-faktor yang mempengaruhi kepuasan pegawai akan dapat mendorong pegawai untuk meningkatkan kinerja tugas mereka, sehingga dapat berkontribusi pada pertumbuhan perusahaan (Shaw et al., 1998). Berdasarkan penjelasan diatas maka dapat dirumuskan hipotesis sebagai berikut:

H4: Kinerja pegawai memediasi pengaruh tata kelola perusahaan terhadap kinerja keuangan.

Gambar 1 menunjukkan model penelitian dalam studi ini yang mempunyai empat hipotesis sebagai berikut:

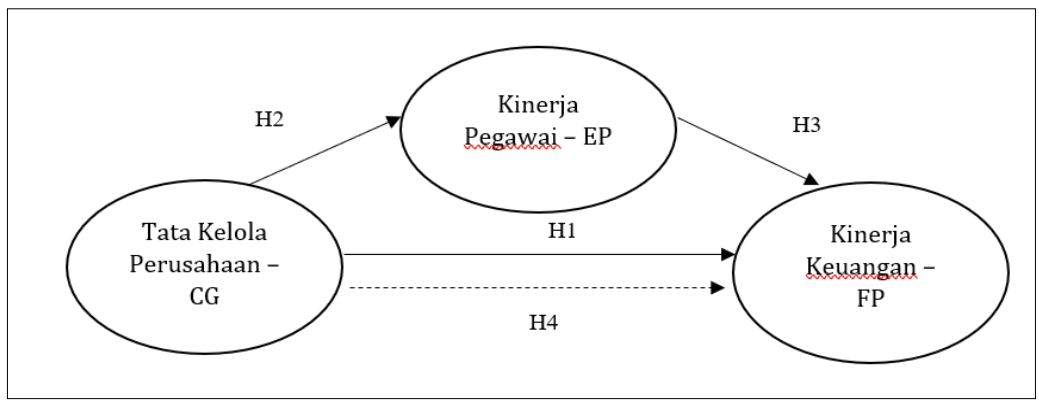

Gambar 1. Model Penelitian 


\section{METODE PENELITIAN}

Penelitian ini akan dilakukan pada BPR BKK Purwokerto yang memiliki 1 kantor pusat dan 25 kantor cabang kecamatan di Kabupaten Banyumas. Responden adalah pimpinan cabang, kasi pemasaran dan kasi pelayanan yang telah bekerja di perusahaan setidaknya tiga tahun. Berdasarkan kriteria tersebut maka dari pengalaman mereka di perusahaan, mereka mempunyai cukup pengetahuan tentang perusahaan untuk menjawab pertanyaan di kuesioner. Analisis unit yang digunakan adalah perusahaan. Wawancara dilakukan terhadap para pegawai untuk mengisi kuesioner yang mempunyai tipe skala Likert 5 butir, di mana skala 1 adalah sangat tidak setuju dan skala 5 adalah sangat setuju.

Alat ukur yang digunakan dalam studi ini diadopsi dari Vebbiantri (2012) yang menggunakan 14 item CG; Antoncic dan Antoncic (2011) menggunakan 3 item EP; dan Hatane (2015) menggunakan 6 item FP. Variabel independent dalam studi ini adalah GCG, dan variabel dependen adalah FP. Variabel EP berperan sebagai variabel intervening. Model Persamaan Struktural atau structural equation modelling (SEM) digunakan untuk menguji pengaruh tiap variabel dalam model penelitian. Jumlah responden yang berpartisipasi dalam studi ini sebanyak 78 responden. Hal ini sesuai dengan pendapat dari Wold (1982), karena data yang terbatas maka pengukuran statistik dilakukan dengan menggunakan metode structural equation modelling-partial least square (SEMPLS).

\section{HASIL DAN PEMBAHASAN}

\section{Analisis Validity dan Reliability}

Prinsip validitas konvergen adalah konstruk harus memiliki korelasi tinggi. Tes dinilai oleh faktor pemuatan (loading factor). Indikator reflektif dikatakan memenuhi convergent validity jika memiliki nilai outer loading yang lebih tinggi dari 0,5. Tabel 1 menunjukkan hasil validitas konvergen, telah terbukti bahwa semua indikator yang digunakan valid. Discriminant validity berkaitan dengan prinsip bahwa perangkat pengukur konstruk yang berbeda tidak boleh memiliki korelasi yang tinggi. Ini dinilai oleh faktor-faktor cross loading factors dari konstruksi. Metode lain yang digunakan untuk menguji discriminant validity adalah memastikan bahwa akar AVE untuk setiap konstruk lebih tinggi daripada korelasi antara konstruk dengan konstruk lain dalam model. Seperti yang ditunjukkan pada Tabel 1 dan Tabel 2, model telah memenuhi uji discriminant validity.

Tabel 1. Cross loading factor

\begin{tabular}{|c|c|c|c|}
\hline & Tata kelola (CG) & Kinerja Pegawai (EP) & Kinerja Keuangan (FP) \\
\hline$\times 1.1$ & 0,925 & & \\
\hline$x 1.10$ & 0,816 & & \\
\hline $\mathrm{x} 1.11$ & 0,892 & & \\
\hline $\mathrm{x} 1.12$ & 0,735 & & \\
\hline $\mathrm{x} 1.13$ & 0,892 & & \\
\hline $\mathrm{x} 1.14$ & 0,842 & & \\
\hline$x 1.2$ & 0,783 & & \\
\hline$x 1.3$ & 0,814 & & \\
\hline$x 1.4$ & 0,902 & & \\
\hline$x 1.5$ & 0,888 & & \\
\hline$x 1.6$ & 0,885 & & \\
\hline$\times 1.7$ & 0,903 & & \\
\hline
\end{tabular}


Performance. Volume 27 Nomor 2 Tahun 2020, 39-48

\begin{tabular}{lll}
\hline$x 1.8$ & 0,778 & \\
\hline$x 1.9$ & 0,774 & \\
\hline$x 2.1$ & 0,862 & \\
\hline$x 2.2$ & 0,871 & \\
\hline$x 2.3$ & 0,766 & 0,827 \\
\hline$y 1.1$ & 0,781 \\
\hline$y 1.2$ & 0,825 \\
\hline$y 1.3$ & 0,783 \\
\hline$y 1.4$ & 0,801 \\
\hline$y 1.5$ & 0,809 \\
\hline$y 1.6$ & \\
\hline
\end{tabular}

Reliabilitas menunjukkan konsistensi dan akurasi instrumen pengukuran untuk melakukan pengukuran. Uji reliabilitas dapat menggunakan dua tes, composite reliability dan cronbach's alpha. Composite reliability mengukur nilai sebenarnya dari reliabilitas konstruk; sedangkan cronbach's alpha mengukur batas keandalan yang lebih rendah. Konstruk harus memiliki nilai cronbach's alpha >0,6; dan nilai composite reliability >0,7. Tabel 3 menunjukkan bahwa model ini telah memenuhi uji reliabilitas.

Tabel 2. Discriminant Validity dan Reliability

\begin{tabular}{cccc} 
& Cronbach's Alpha & Composite Reliability & Average Variance Extracted (AVE) \\
\hline CG & 0,969 & 0,973 & 0,717 \\
\hline EP & 0,781 & 0,873 & 0,696 \\
\hline FP & 0,892 & 0,917 & 0,647 \\
\hline
\end{tabular}

\section{Inner Model dan Goodness of Fit}

Inner Model adalah model struktural untuk memprediksi hubungan kausal antara variabel laten. Melalui proses bootstrap, parameter uji T-statistik diperoleh untuk memprediksi keberadaan hubungan kausal yang signifikan (T-stat> 1,96). Nilai $R$ square digunakan untuk mengukur tingkat variasi dari perubahan variabel independen terhadap variabel dependen. Namun, $R$ square bukanlah parameter absolut dalam mengukur keakuratan model prediksi, karena hubungan teoritis dasar adalah parameter utama untuk menjelaskan hubungan kausalitas.

Tabel 3 menunjukkan bahwa T-statistic untuk setiap hubungan lebih tinggi dari 1,96 dan coefficient positif. Hal tersebut menunjukkan bahwa terdapat hubungan signifikan secara positif. Ini berarti bahwa hipotesis yang diuji dalam penelitian ini diterima. Tabel 3 menunjukkan $R$ square untuk setiap persamaan. Model persamaan yang dikembangkan adalah:

Sebelum ada variabel EP:

$$
F P=0,929 C G+e \quad R^{2}=0,864
$$

Setelah ada variabel EP (mediasi):

$$
\begin{array}{ll}
E P=0,931 C G+e & R^{2}=0,866 \\
F P=0,019 C G+0,960 E P+e & R^{2}=0,956
\end{array}
$$


Performance. Volume 27 Nomor 2 Tahun 2020, 39-48

Tabel 3. Hasil Path coefficients

\begin{tabular}{lcc}
\hline & Path Coefficients & T-statistic \\
\hline Sebelum ada mediasi & & \\
\hline CG -> FP & 0,929 & 6,349 \\
\hline Setelah ada mediasi & & \\
\hline CG -> EP & 0,931 & 6,474 \\
\hline CG -> FP & 0,019 & 0,001 \\
\hline EP -> FP & 0,960 & 2,849 \\
\hline
\end{tabular}

Goodness of fit dalam model diuji dengan menggunakan Stone-Geisser Test $\left(Q^{2}\right)$. Tes $Q^{2}$ digunakan untuk mengukur seberapa baik nilai observasi yang dihasilkan dari model.

$$
\begin{aligned}
& Q^{2}=1-\left(1-R_{1}^{2}\right)\left(1-R_{2}^{2}\right) \\
& Q^{2}=1-((1-0,866)(1-0,956) \\
& \quad=0,994=99,4 \%
\end{aligned}
$$

Hasil $Q^{2}$ menyiratkan bahwa model yang digunakan dalam penelitian ini dapat menjelaskan informasi dari data sebesar 99,4\%. Tabel 4 menunjukkan kemampuan variabel mediasi dalam memediasi. Tabel tersebut menunjukkan bahwa kinerja pegawai (EP) berhasil menjadi variabel pemediasi pada pengaruh tata kelola perusahaan (CG) terhadap kinerja keuangan (FP).

Tabel 4. Mediasi dan pengaruh langsung

\begin{tabular}{cccc}
\hline Model mediasi & Kekuatan mediasi & Pengaruh langsung CG $->$ FP & Hasil \\
\hline CG $\rightarrow$ EP $->$ FP & $=0,931 \times 0,960=0,894$ & 0,019 & Mediasi $->$ langsung \\
\hline
\end{tabular}

\section{Diskusi dan Implikasi Manajerial}

Studi ini menemukan bahwa terdapat hubungan positif dan signifikan antara tata kelola perusahaan (CG) terhadap kinerja pegawai (EP). Hasil penelitian ini mendukung penelitian Amri et al (20016), Febriani et al. (2016) dan Situmorang dan Simanjuntak, (2019). Kinerja pegawai (EP) ditemukan positif signifikan dalam mempengaruhi kinerja keuangan (FP). Hasil ini sejalan dengan penelitian Hatane (2015). Hasil penelitian juga menunjukkan bahwa kinerja pegawai (EP) sebagai variabel pemediasi hubungan antara tata kelola perusahaan (CG) terhadap kinerja keuangan (FP).

Responden dalam penelitian ini berpendapat bahwa untuk mempertahankan tata kelola perusahaan maka perusahaan menghargai pegawai atas upaya mereka untuk ikut serta dalam melaksanakan tata kelola perusahaan dengan baik. Dengan menerapkan prinsip-prinsip tata kelola perusahaan, organisasi berhasil memotivasi pegawai untuk meningkatkan kebiasaan menerapkan tata kelola perusahaan yang baik sehingga akan mengarah pada budaya tata kelola yang baik (good corporate governance). Dengan demikian, jika suatu organisasi memiliki tata kelola yang baik maka hal itu akan membentuk kinerja pegawai yang lebih baik. Pegawai akan dapat menyesuaikan diri dengan tata kelola perusahaan yang baik yang dijalankan perusahaan sehingga perusahaan dapat terus eksis di lingkungan bisnis yang dinamis.

\section{KESIMPULAN}

Hasil penelitian ini mengungkapkan pengaruh langsung dan tidak langsung tata kelola perusahaan (corporate governance) terhadap kinerja keuangan. Pengaruh tidak langsung yang digunakan adalah kinerja pegawai sebagai variabel intervening. Menggunakan model persamaan struktural sebagai alat statistik, hasilnya menunjukkan bahwa kinerja pegawai berperan dalam memediasi pengaruh tata kelola perusahaan terhadap kinerja keuangan perusahaan. Organisasi, terutama dalam bidang bisnis, harus memperhatikan prinsip-prinsip tata kelola perusahaan yang 


\section{PERFORMANCE}

Jurnal Personalia, Financial, Operasional,

Marketing dau Sistem Informasi

Performance. Volume 27 Nomor 2 Tahun 2020, 39-48

baik. Penelitian ini menunjukkan bahwa komitmen pegawai terhadap organisasi akan meningkat seiring dengan meningkatnya penerapan tata kelola perusahaan yang baik (good corporate governance/GCG).

Selanjutnya, upaya organisasi dalam implementasi prinsip-prinsip GCG akan membawa hasil pada peningkatan kinerja pegawai, sehingga pada akhirnya akan mengarah pada pencapaian pertumbuhan laba. Studi ini menguji pengaruh tata kelola perusahaan (CG) dan kinerja pegawai (EP) pada kinerja keuangan (FP) di perusahaan bank perkreditan rakyat (BPR-BKK) di Purwokerto. Hasil yang berbeda dapat ditemukan jika penelitian di masa depan menggunakan ruang lingkup yang berbeda atau karakteristik yang berbeda. Perbaikan dalam bidang ini selalu diperlukan karena lingkungan bisnis yang dinamis. Bidang penelitian ini juga terkait dengan pribadi orangorang dalam organisasi yang akan selalu berubah.

\section{DAFTAR PUSTAKA}

Aboagye, Q. A., \& Otieku, J. (2010). Are Ghanaian MFIs' performance associated withcorporate governance? Corporate Governance. The international journal of business insociety 10 (3): 307-320. DOI: 10.1108/14720701011051938

Ahmed, E. \& Hamdan, A. (2015). The impact of corporate governance on firm performance: evidence from Bahrain Bourse. International Management Review, Vol. 11 No. 2, pp. 21-37.

Atmaja, Y.G., Riswan \& Tohir. (2015). PERUSAHAAN, DAN LEVERAGE PERUSAHAAN TERHADAP KINERJA KEUANGAN SEKTOR PERBANKAN (STUDI PADA PERUSAHAAN PERBANKAN YANG TERDAFTAR DI BURSA EFEK INDONESIA (BEI) TAHUN 2009-2013). Performance: Jurnal Personalia, Financial, Operasional, Marketing Dan Sistem Informasi, Vol 21, No 1 (2015) http://jp.feb.unsoed.ac.id/index.php/Performance/article/view/507/542

Amri, Saiful., Haryono. A.T., \& Warso, M.M., (2016). Pengaruh Good Corporate Governance Terhadap Kinerja Pegawai PT. Aditec Cakrawiyasa Semarang. Journal of Management Vol.02 No.02, Maret 2016

Andriana, Abigail \& Panggabean, Rosinta Ria. (2017). The Effect of Good Corporate Governance and Environmental Performance on Financial Performance of the Proper Listed Company on Indonesia Stock Exchange. Binus Business Review, 8(1), May 2017, 1-8

Andriyan, Okky \& Supatmi. (2010). Pengaruh Mekanisme Corporate Governance Terhadap Kinerja Keuangan Bank Perkreditan Rakyat, Jurnal Akuntansi dan Keuangan Indonesia, Vol. 7. No. 2. pp. 187-204.

Antoncic. J.A \& Antoncic, B. (2011). Employee satisfaction, iuntrapreunership and firm growth: a model. Industrial Management and Data System, 111(4). 589-607

Bauer, R., Frijns, B., Otten, R., \& Tourani-Rad, A. (2008). The impact of corporate governance on corporate performance: Evidence from Japan. Pacific-Basin Finance Journal, 16(3), 236-251.

Berle, A. \& Means, G. (1932). The Modern Corporation and Private Property. New York: Macmillan

Bratton, V. K. (2004). Affective morality: The role of emotions in the ethical decision-making process. Digital Dissertations, 65(12). (UMI No. 3156058) 


\section{PERFORMANCE}

Jurnal Personalia, Financial, Operasional,

Marketing dau Sistem Informasi

Performance. Volume 27 Nomor 2 Tahun 2020, 39-48

FCGI. 2001. Peranan Dewan Komisaris dan Komite Audit dalam Pelaksanaan Corporate Governance (Tata Kelola Perusahaan). Jilid II, Edisi 2

Febriani, J.I., Musadiq, M.A. \& Afrianty, T.W. (2016). Pengaruh Good Corporate Governance Terhadap Kinerja (Studi Pada Pegawai PT Pos Indonesia (Persero) Tuban). Jurnal Administrasi Bisnis (JAB). Vol. 32 No. 1 Maret 2016

Hamdani, N.A., Maulani, G.A.F. \& Supriyatna, A. (2018). Contributing Factors of Good Corporate Governance and Employee Performance to Bank Performance. The Journal of Social Sciences Research. ISSN(e): 2411-9458, ISSN(p): 2413-6670 Special Issue. 4, pp: 235-237, 2018

Hatane, Saarce Elsye. (2015). Employee Satisfaction and Performance as Intervening Variables of Learning Organization on Financial Performance. Procedia - Social and Behavioral Sciences 211 (2015) 619 - 628. 2nd Global Conference on Business and Social Science-2015, GCBSS, 17-18 September 2015, Bali Indonesia.

Jensen, M.C., \& W.H. Meckling, (1976). Theory of The Firm: Managerial Behavior, Agency Costs and Ownership Structure. Journal of Financial Economics, 3 (4), 305-360.

Kangmartono, B.G.H., Yusniar, M.W. \& Jikrillah, S. (2018). Pengaruh Mekanisme Corporate Governance Terhadap Kinerja Keuangan Bank Perkreditan Rakyat Di Indonesia. Jurnal Wawasan Manajemen, Vol. 6 Nomor 2, 2018

Laksana, J. (2015). Corporate Governance Dan Kinerja Keuangan (Studi Kasus Pada Perusahaan Perbankan Yang Terdaftar Di BEI Periode 2008-2012). E-jurnal Akuntansi Universitas Udayana 11.1 (2015): 269-288

Mahrani, Mayang \& Noorlailie, Soewarno. (2018). The effect of good corporate governance mechanism and corporate social responsibility on financial performance with earnings management as mediating variable. Asian Journal of Accounting Research Vol. 3 No. 1, 2018 pp. 41-60.

OECD. (2004). OECD Principles of Corporate Governance. http://webcache.googleusercontent.com/search?q=cache:QXXKYvWVIfoJ:www.oecd.org/c orporate/ca/corporategovernanceprinciples/31557724.pdf $\& c d=2 \& h l=i d \& c t=c \mid n k \& g l=i d$

Paniagua, J., Rivelles, R., \& Sapena, J. (2018). Corporate governance and financial performance: The role of ownership and board structure. Journal of Business Research 89 (2018) 229-234

Saidat, Z., Silva, M. \& Seaman, C., (2018). The relationship between corporate governance and financial performance: Evidence from Jordanian family and nonfamily firms, Journal of Family Business Management, Vol. 9 No. 1, pp. 54-78. https://doi.org/10.1108/JFBM-11$\underline{2017-0036}$

Shaw, J.D., Delery, J.E., JenNins, G.D.Jr \& Grupta.N. (1998). An OrganizationalYlevel Analysis of Voluntary and Involuntary Turnover. Academy of Management Journal, 41(55), 511-525.

Situmorang, Christina Verawaty \& Simanjuntak, Arthur., (2019). Pengaruh Good Corporate Governance Terhadap Kinerja Keuangan Perbankan Yang Terdaftar di Bursa Efek Indonesia. Jurnal Akuntansi dan Bisnis: Jurnal Program Studi Akuntansi, 5 (2) November 2019. 
Jurnal Personalia, Financial, Operasional,

Marketing dam Sistem Informasi

Performance. Volume 27 Nomor 2 Tahun 2020, 39-48

Tim Informasi Hukum, Direktorat Hukum BI. (2010). Surat Edaran Bank Indonesia No. 12/14/DKBU - Pelaksanaan Pedoman Akuntansi Bank Perkreditan Rakyat. https://www.bi.go.id/id/peraturan/perbankan/Pages/se 121410.aspx

Vebiantri, Orie. (2012). Implementasi prinsip Good Corporate Governance ditinjau dari persepsi Pegawai pada PT. Antam Tbk. file:///E:/PENELITIAN\%202019/JURNAL\%20RUJUKAN/S44013Orie\%20Vebbiantri\%20Kuisioner\%20persepsi\%20kayawan\%20thd\%20GCG

Wold, H. (1982). Soft Modelling: the basic design and some extensions. In: Joreskog K, G. Wold, $\mathrm{H}$ (eds) Systems under indirect observation. Causality, structure, prediction, vol II. NortHolland, Amsterdam, pp. 1-54

Xu, X., and Xia, Y. (2012). Internal corporate governance and the use of IPO over-financing: Evidence from China. China Journal of Accounting Research, 5(3), 231- 249. https://doi.org/10.1016/j.cjar.2012.08.003

Yilmaz, liker. (2018). Corporate Governance and Financial Performance Relationship: Case for Oman Companies. Journal of Accounting, Finance and Auditing Studies 4/4 (2018) 84-106.

Zahargier, M. S., \& Balasundaram, N. (2011). Factors affecting Employees $\Gamma$ Performance in ReadyYMade Garments (RMGs) Sector in Chittagong. Bangladesh. Economic Sciences Series, 63(1), 9-15 